\title{
Linguistic Turns: Performing Postmodern Poetries
}

\author{
STAN SMITH \& ANTONY ROWLAND
}

The linguistic turn is as old as poetry itself. What Seamus Heaney calls the "suggestive etymology of the word "verse"" (Preoccupations, 1980), has been frequently remarked. Derived from the Latin 'versus', a turning, it refers, according to the Oxford English Dictionary, to the turning at the end of each poetic line. The unintentional ambiguities of this last phrase indicate that poetry also represents a different kind of turning, which carries to extremes a process implicit in the slippery duplicity of all language. Pun, paronomasia, metaphor and metonymy, double entendre, the linguistic turning of one thing into another, effect in poetry, as in everyday discourse, a perpetual translation of experience. Etymologically, indeed, the Greek 'metaphor' is virtually a synonym of the Latin-derived 'translation', a carrying over or across of meanings from one place to another. Such a transfigurative or redemptive function, the conversion of events into the abstract medium of language, creating a new and possibly renewed version of things, has been ascribed to poetry ever since the Renaissance Neoplatonists sought to rescue it from the odium Plato bestowed on it, expelling it from his Republic as a lying discourse, a dangerous corrupter of the truth. Renaissance literary criticism is full of play on the trope of a language that, in Sir Philip Sidney's famous words, converting and contraverting Plato, substitutes 'a golden world' for 'nature's world of brass'.

Neoplatonism remains a potent influence behind the postmodern conviction that consciousness, reality, and truth itself, as we experience them, are constructed in language, and any alleged access to an ulterior, pre-existent real, to some untrammelled 'real presence', remains an ideological operation and imposture. Many of the essays in this volume resist the notion of an unmediated 'reality' which precedes language and consciousness, but they do not subscribe to an uncritical relativism which sees all 'versions' of events as equally valid. Ted Hughes's poetry posits 'Being' as some originary, pre- 
linguistic site of celebration, but Antony Rowland demonstrates that such a 'truth' of existence constitutes a philosophical tall tale, a linguistic construct that may be, as Theodor Adorno has contended in another context, as empty and clichéd as the rustle of wind in bad poems (Negative Dialectics, 1973). Nevertheless, the ramifications of that capital 'B' produce some of Hughes's best poems. Stan Smith traces the continuity between the supposedly avant-garde Kulturkampf of 1990s New Poetry and 'New Generation' writings and the preoccupations of earlier 'new turns' and U-turns in the 1950s and 60s. Beyond this, he suggests, lies the populist essentialism of Wordsworth's 1800 Preface to Lyrical Ballads, with its cult of 'the real language of men' as the vehicle for discovering 'the beautiful and permanent forms of nature' and 'the primary laws of our nature.' To see the politics here as a version of pastoral like Wordsworth's is not to invalidate its polemic intervention at a real turning point of cultural history.

Kai Merten insists on the split between the speech act, as the philosopher J. L. Austin defined it, and subsequent performances of the act, but he also defends the political impetus of the verse he discusses, arguing that, whereas for Derrida literature is a site of verbal polyvalency where anything goes, the schoolroom, by contrast, is an ideologically pre-empted apparatus in which some readings (performances) are prioritised and others repressed. Both Merten's and Blakeman's use of Austin parallels Robert Sheppard's investigation of the split between the 'saying' and the 'said' posited by Levinas. The 'saying' presents linguistically innovative poets with the heady, utopian opportunity to depose the tyranny of the 'said' in more conventional post-Movement poetry, while simultaneously realising that both categories are linguistic constructs. Thus, he argues, Tom Raworth's predilection for 'what was to one side or not real' in his ramblings around Marseilles goes on to form the basis for the verbally open-ended sequence Eternal Sections.

W. H. Auden alluded to the lineage of Neoplatonic apologia when he picked up Shakespeare's line, 'The Truest Poetry is the Most Feigning', as the title for one of his poems. Auden's observation here that 'Good poets have a weakness for bad puns' pulls out all the stops on Plato's moral-political organon. If Plato expelled the poets from his Republic because the playfulness of poetry was not consonant with his idea of moral and political rectitude ('the Good'), Auden mischievously suggests that poetic 'goodness' lies precisely in the (moral) 'weakness' Plato condemned: language's capacity to lie, to 
invent fictions, discursively to turn one thing into another by means of the pun which is ludically 'good' in inverse proportion to its verbal perversity (the badder the better). Auden's own favourite pun lies, probably, in the word 'lie' itself, in which physical placement and deceit are inextricably involved. 'From such ingenious fibs are poems born', he insists, repeating the Platonic canard without ducking the irresponsibility of the poet confronting a brutally unpoetic history:

No metaphor, remember, can express

A real historical unhappiness.

Your tears have value if they make us gay:

O Happy Grief! is all sad verse can say.

If a political regime collapses, so that overnight 'Poets are suspect with the New Regime' as they were for Plato or Stalin (the poem was written in September 1953, a few months after the latter's death), a love poem can always be converted, by wily linguistic legerdemain, into an encomium for the new dictator. 'Honest Iagos' Auden observes, deploying the adjective with a droll irony, will write 'Shame! ... Toady! Hypocrite!' in your margins, but - equally ironic this use of 'true' - 'True hearts, clear heads, will hear the note of glory / And put inverted commas round the story.' Such postmodern scare quotes are the guarantee that poems, unlike politicians and the spin-doctors of whom Shakespeare's Iago is the prototype, will never lie to us, for poetry's duplicitous discourse comes qualified with the contractual proviso that we are not required to believe, but only, in Coleridge's formula, willingly to suspend disbelief.

That ideological construct, 'Man', the poem argues, being 'The only creature ever made who fakes', has 'no more nature in his loving smile / Than in his theories of a natural style,' and only 'tall tales, the luck of verbal playing, / Can trick his lying nature into saying' a truth that finds its significance only in reticence. As Auden wrote in 'Words' (1956): 'A sentence uttered makes a world appear / Where all things happen as it says they do.' 'Syntactically though, it must be clear', the poem goes on, 'One cannot change the subject half-way through'. But its own play on the word 'subject' does exactly that, by greasily slipping from meaning 'theme' to meaning subject of the verb, and then to meaning conscious and, ultimately, political subject. In the Spanish usage, a pronunciamento is not just a decree, but a coup d'état. In the historical world, dictators' words can exile Thucydides, send Mandelstam to die in the camps at Voronezh, have Lorca shot and Neruda 
murdered, and their deaths dissembled as 'from natural causes'. Far from being an irresponsible fiddling while Rome burns, contemporary poetry's linguistic turn situates it precariously in this monstrous play (we use the word advisedly) between the historical world where dictators seize the means of communication and issue diktats, and the linguistic realm where the state is translated into statements, into lies, hypocrisy, or, aesthetically, into fictions. As Stan Smith suggests, the oppositional, counter-cultural postures of the poets of the last two decades may or may not be 'genuine' acts of allegiance to one or more form of identity politics, but they remain primarily, in Yeats's words, 'metaphors for poetry', exercises in a traditional genre.

Hence the suspicion displayed towards, but also valorisation of, literature by some schools of marxism. Terry Eagleton worried in 'Irony and Commitment' (1979) that literature might be an intrinsically bourgeois form with no place for proletarian politics, but came round to the view that the phrase 'committed literature' is a tautology rather than an oxymoron. In 'Commitment' (1977), Theodor Adorno championed autonomous art above committed tripe. For all his fears, however, about the slipperiness of poetic language, the lyric remains a possible site for the co-existence of autonomous art and a subtle politics, as is exemplified for him by the poetics of Joyce and Beckett. Adorno's resistance to Marxism, outlined in the preface to Negative Dialectics, can be ascribed to a moment in which he comes clean, and declares himself against all political dogma. Linguistic resistance to a utopian world of 'pure' ideology can be evidenced from a reversed position in relation to the poetry of Medbh McGuckian. For all of McGuckian's struggle to evade the fixed referent in her verse, as Helen Blakeman argues so persuasively here, the ghost of politics returns to haunt the poetry in, for example, her engagement with Irish languages. Much of the poetry discussed in this collection wobbles creatively between identity politics and a postmodern lightness of being in which the real vies with a globalised virtual reality which never wants to pay its taxes. That resistance towards an unmitigated 'real' can itself be a political act is evidenced in Mark Doty's investigation of the discursive nature of AIDS discourse. As Joanne Rendell likewise demonstrates, HIV-positive status, like gender, is discursively produced, and made 'real' through repeated citation and re-iteration as 'fact'.

The linguistic playfulness, 'verbal playing', at the heart of contemporary poetry does not exclude it from speaking of serious, indeed 
deadly matters. Wallace Stevens could write sternly, in 'The Idea of Order at Key West' (Ideas of Order, 1935), of 'The maker's rage to order words of the sea'. But he had already written, in 'The Comedian as the Letter C' (Harmonium, 1923), in a dandyishly rococo idiom and syntax, of the poet's inability to 'stem verboseness in the sea, / The old age of a watery realist', and of the final inseparability of 'The fabulous and its intrinsic verse'. Stevens's 'Metaphors of a Magnifico' (Harmonium) refuses to say just what the relation is between the two nouns in its title: is the magnifico subject (enunciator) or object (enunciated) of the metaphors? The poem is equally reluctant to specify the relation between its title and its supposed 'subject': 'Twenty men crossing a bridge / Into a village'. 'Magnifico', however, is a term of political power, originally bestowed on the magnates of Venice, but in 1923, when this poem was written, most recently applied to the dictator Mussolini. The pluralist relativity of subjectpositions in a multiply perceived world, which seems to be the poem's 'subject', raises too the possibility that these twenty men are the (political) subjects of a single man, the boots clumping in unison those of soldiers. While on the one hand they may be 'twenty men crossing twenty bridges / Into twenty villages', they can also be seen as 'one man / Crossing a single bridge into a village.' Ultimately, the poem concludes self-reflexively, 'the meaning escapes', but it has also been invented in the very act of losing it. Stevens's Man with the Blue Guitar (1937), asked to play a tune "“Of things exactly as they are", can only reply that "Things as they are / Are changed upon my blue guitar", leading the poet in turn to conclude that "The blue gui$\operatorname{tar}$ / Becomes the place of things as they are.' Against this, however, one should set the advice from a guide to Stage Noises and Effects which Don Paterson set as epigraph to his first collection, Nil Nil (1993): 'Slamming Door: A real door slammed off-stage gives the best effect.'

The linguistic turn in contemporary poetry, then, is turning an old trick, and this is why we have pluralized the phrase by calling this special issue 'Linguistic Turns'. For a turn is also a performance, that of a stand-up comedian or acrobat, twisting the self into unnatural postures, moral or physical, prefacing every verbal or corporeal contortion with an initial 'What if ....?' This performative aspect of poetry is discussed by both Kai Merten and Joanne Rendell. Merten analyses the performance of the classroom poem in Heaney and Tony Harrison, while Rendell draws on Judith Butler's notion of gender as 
performative. This does not mean that gender is performance in the sense of an optional act. Rendell takes an Althusserian line in arguing that the postmodern subject is interpellated into subjectivity through the imitation and citation of gender scripts. Every modern poem in this sense simultaneously claims to speak of 'things as they are' and performs itself as a poem in the act of doing so. As Rainer Emig punningly puts it, poets 'soil' themselves by burying, and digging for, the detritus of history, combining a desire for groundedness with a sense of the mirage-haunted 'deserts of the real'.

This issue is dedicated to the memory of David Gascoyne, who died, aged 85, in November 2001. Literary history has not yet returned - or re-turned - a settled verdict on his verse, and no doubt any such would be overturned in turn by the whirligigs of time, for the return of the repressed is the one good turn we can be guaranteed amidst the steady turnover of all literary history. But there can be little doubt about Gascoyne's literary-historical importance, as Alan Munton's essay eloquently records. Gascoyne's pioneering of surrealism in the 1930s and of the New Apocalypse in the 1940s, with their fracturing of linguistic convention, syntactical and narrative coherence, metaphoric consistency, carried over into English some of the most subversive impulses of European poetry in the years entre deux guerres. This uprooting and turning over of language was seen at the time as offering a 'truer' access to reality, freeing the 'authentic' unconscious self from an ideologically orchestrated commonsense in which consciousness dissembled itself and the world around it. Dislocating and disrupting language, these writers thought, could liberate it from the tyranny of meaning, letting the meaning escape. Yet at the same time, like his mentors the French and Spanish Surréalistes, Gascoyne maintained an intense political commitment, above all to the cause of Republican Spain. Essays in this collection move likewise between the playfulness of the poetic performance, 'turns' upon a stage, and the earnestness with which the same poetry addresses the turns and turn-ups for the book of history's turning world. Kai Merten's closing essay returns us to the classroom, and that, of course, is where most of us witness the encounters of word and world, and spin our own tall tales. It is also where, in the end, 'The meaning escapes'. As Stevens wrote in 'Blue Guitar', seeing poetry as both an absence in, of and from reality, and its realest presence: 
Poetry is the subject of the poem,

From this the poem issues and

To this returns. Between the two, Between issue and return, there is

An absence in reality,

Things as they are. Or so we say. 